Forthcoming in Dialogue: Canadian Philosophical Review.

\title{
On the Right to Justification and Discursive Respect
}

\author{
THOMAS M. BESCH University of Hradec Kralove
}

ABSTRACT: Rainer Forst's constructivism argues that a right to justification provides a reasonably non-rejectable foundation of justice. With an exemplary focus on his attempt to ground human rights, I argue that this right cannot provide such a foundation. To accord to others such a right is to include them in the scope of discursive respect. But it is reasonably contested whether we should accord to others equal discursive respect. It follows that Forst's constructivism cannot ground human rights, or justice, categorically. At best, it can ground them hypothetically. This opens the door wide for ethical foundations of human rights.

RÉSUMÉ: Le constructivisme de Rainer Forst fait valoir que le droit à la justification fournit une base de la justice qui ne peut raisonnablement être rejetée. En mettant l'accent de façon exemplaire sur sa tentative de fondation des droits de l'homme, je soutiens que ce droit ne peut pas fournir une telle fondation. Accorder ce droit aux autres revient à les inclure dans le champ d'application du respect discursif. Or, le fait que l'on doive accorder aux autres un respect discursif égal fait l'objet d'une contestation sérieuse. II en résulte que le constructivisme de Forst ne peut pas fonder catégoriquement les droits de l'homme, ni la justice. Au mieux, il les fonde de façon hypothétique. Cela ouvre grand la porte aux fondements éthiques des droits de l'homme.

\section{Introduction}

Rainer Forst has advanced a variant of practical constructivism that takes it not only that "there are reasonable foundations for a conception of justice, but also that it goes back to a single root-that is, the various aspects of justice in social and political contexts, and even beyond national borders, ultimately refer to a normative core: the one basic human right to justification." 1 As this passage heralds, Forst's approach situates the right to justification, or proper respect for it, at the reasonably non-rejectable foundation of many things-e.g., social and political domestic justice and transnational justice, morality, a democratic ethos, reasonable deliberative democracy, political non-domination, reasonable toleration, public justification, and, most relevant here, human rights. What I want to do here is to examine whether a Forst-type right to justification can indeed play the foundational role that Forst's constructivism assigns to it, with an exemplary focus on the systematic role that this right plays in Forst's more recent attempt to justify human rights on 'categorical,' reasonably non-rejectable grounds. ${ }^{2}$

Before I outline my argument, let me fix ideas by noting why, according to Forst,

1 Forst (2012), p. vii.

2 See Forst (2010) and (1999). Key components of his view are worked out in Forst (2004), (2003a), (2002), (2014a) and (2014b). 
there is a need for a categorical grounding of human rights. In his view, this need springs from the fact that human rights have a "moral life"-whether or not they are also recognized politically, legally, or socially. 3 And, as moral rights, they claim universal authority: everyone has them and everyone must respect them. Yet, Forst insists, their strong validity claims cannot properly be redeemed where they are justified 'hypothetically,' or on grounds-e.g., views, volitions, commitments, or conceptions of the good, widely conceived - that reasonable people can reasonably reject. Instead, they must be justified categorically, i.e., on grounds that no reasonable person can reasonably reject. For Forst, this marks a defining shortfall of "ethical" accounts of human rights. ${ }^{4}$ "Ethical" accounts are accounts that justify these rights hypothetically by grounding them in conceptions of the good that are, or can be, the subject of reasonable disagreement. Accordingly, a main objective of Forst's approach is to provide an alternative to 'ethical' accounts by identifying a categorical basis to which the justification of human rights should appeal. The right to justification here takes centre stage. For Forst, this right, or that everyone has it and that we must respect it, cannot reasonably be rejected. And it requires that people be accorded a particularly strong kind of discursive moral standing - I shall later refer to it as constitutive discursive standing (see Sections 4 and 5, below) - such that moral and political reasons and principles (amongst other things) that affect them must be justifiable to, or suitably acceptable by, them. Forst claims that discourses that fully respect this 'one basic right' will allow us to establish at least some non-basic human rights as entitlements that cannot be rejected on grounds that are suitably acceptable by all affected others.

There is much in this line of thought that has deep moral appeal. This starts with, but is not limited to, the idea that we should accord to people a moral standing such that moral or political standards that affect them must be suitably justifiable to them. However, it is important here to distinguish between normative substance and doctrinal aspirations, or whatever aims are being pursued where a doctrine tries to appropriate this idea by from the start defining it in doctrinally specific and potentially parochial terms. That is to say, substantively, and other things being equal, the idea that everyone should be accorded such a standing is highly plausible, if not compelling (or so it seems to me). It is also a theoretically well-entrenched idea. For example, it is the emancipatory moral core of many liberal conceptions of justice that build on the view that a social or political order can duly respect the people who live under it—or their dignity, their freedom and equality, or their autonomy - only if it is suitably justifiable to them. ${ }^{5}$ However, we should

3 Forst (2010), p. 711.

4 Forst takes issue especially with the 'ethical' approaches of James P. Griffin and John Tasioulas: see Griffin (2008) and Tasioulas (2007). Forst offers his approach, as well, as an alternative to 'politicallegal' views that anchor human rights in contingent political, legal, or other institutions and conventions, e.g., as advanced in Rawls (1999), or Beitz (2009). Forst's discourse-ethical idea of the "ethical" is technical: see Forst (2012), pp. 62-78. "Ethical" views by definition do not meet a standard of reciprocal acceptability by all affected others. Practical views that meet this standard are 'moral' and, as they meet this standard, reasonably non-rejectable. I shall not use the terms 'ethical' and 'moral' in this technical sense, and I will suppose that it is an open question whether moral views are, or claim to be, reciprocally acceptable by all affected others. On the discourse-ethical distinction between "ethical" and "moral" views: see Besch (2014), p. $220 f$.

5 See Forst's works and Rawls (1993) and (2001); Macedo (1991); Larmore (1996) and (2008); Quong 
not doctrinally monopolize this idea from the outset by defining it in philosophical, moral, or other terms that are reasonably contested and that stand in need of justification. This is so at least if-in fact, especially if-we agree that this idea is profound enough to merit a foundational role in our thinking about, as Forst puts it above, "the various aspects of justice in social and political contexts." After all, if this idea is profound enough to play such a role, it is profound enough, as well, to apply to the terms by which a reasonably contested doctrine construes what this idea does or does not call for in a given context. And, perhaps ironically, this applies, as well, where we construe things in constructivist terms that aspire to give much justificatory force to what actual people can or cannot accept coherently. 6

Now, Forst's constructivism from the outset attaches a doctrinal meaning to the right to justification. He does not simply take it that people have, or should be accorded, a moral standing such that the reasons or principles that affect them must be justifiable to them on grounds that merit their acceptance. Rather, he construes the right to justification in light of the stronger idea that reasons or principles depend for their justification, or normative authority, on their acceptability. That acceptability must have this strong, justification-constitutive status is a constructivist conception-one, moreover, that, while arguably much speaks in its favour, is reasonably contested and that stands in need of justification (I shall return to this later). Thus, to construe the right to justification as a right to constructivist justification is to understand it in doctrinal, reasonably contested terms. But, if that is so, how, we may wonder: could a right to justification so construed provide a reasonably non-rejectable foundation of human rights (or, for that matter, of anything else)? And if we agree that the right to justification so construed can ground human rights, should we not conclude that whatever provides the reasonably non-rejectable foundations of human rights cannot be the right to justification, but would have to be whatever it is, if anything, that gives us reasonably non-rejectable reasons in the first place to construe it in constructivist terms?

The case that I make here, then, is negative, and limited. I shall argue that Forst's account does not provide a categorical justification of human rights on reasonably nonrejectable grounds. Forst attaches a doctrinal, constructivist interpretation to this right, or the kind of justification it calls for. As we shall find, this means that his account ultimately shares the fate of 'ethical' justifications of human rights. That is, at best, Forst's constructivism justifies human rights hypothetically by grounding them in a conception of the good that is reasonably contested and that stands in need of justification-namely, the good of constitutive discursive standing. This opens the door wide for an 'ethical' defence of this good. And while such a defence will inevitably invoke value judgments that can reasonably be rejected and that hence would not meet Forst's constructivist justification requirements, this does not constitute an objection that is available from the perspective of this brand of constructivism.

I shall proceed as follows. In Section 2, I distinguish between two lines of argument in Forst's account. A first line of argument offers as the sought-after foundation of human rights a standard of reciprocal and general acceptability (or RGA, for short) in

(2011). See also the seminal Waldron (1987).

6 On constructivism, see Besch (2014), and below; Ronzoni (2010); LeBar (2008); Forst (2002), esp. p. $173 \mathrm{ff}$. 
conjunction with the view that this standard commits us to accord to others a right to justification. The second line of argument offers as the sought-after foundation a conception of moral respect as discursive respect, as I will call it-namely, a form of moral respect that commits us to accord to others constitutive discursive standing. In Section 3, I engage the first line of argument. I argue that a reconstructively adequate account of our moral or political validity claims will not entail that they commit us to Forst's RGA. In Sections 4 and 5, I engage the second line of argument. I argue that any conception of moral respect as discursive respect will be reasonably contested if constructivism is. At the same time, many conceptions of discursive respect are possible, and each will involve reasonably contested content. A conception of moral respect as discursive respect hence cannot provide the sought-after, reasonably non-rejectable grounding of human rights. Forst's constructivism may be able to evade these results if it supposes a constructivist conception of reasonableness. As I argue in sections 6, however, this exit route is blocked. Thus, his variant of constructivism at best grounds human rights hypothetically in the good of (equal) constitutive discursive standing. Even from Forst's own point of view, then, this opens the door wide for 'ethical' foundations of human rights.

One more remark is necessary before I start. I said earlier that my discussion engages Forst's constructivism with an exemplary focus on his account of human rights. That this focus is exemplary means that the ideas that I will take issue with are not specific for Forst's account of human rights; rather, they mark defining features of his brand of constructivism-features, that is, that he seeks to apply to the task of grounding such rights-and it is the promise of this brand of constructivism, and especially the systematic use it makes of the idea of a right to justification, rather than its application to the special case of this task, that marks my main interest here.

\section{Forst's Account: Components and Structure}

To begin with, there is an ambiguity in the systematic architecture of Forst's account of human rights. There are two distinct, albeit compatible lines of thought at the systematic core of this account. Each takes a different path to situating the idea of a right to justification at the foundation of human rights-or other, substantive moral or political principles, for that matter. To start with what these two lines of thought have in common, the following views mark key components of Forst's 'reason-based' constructivism:

(1) Practical views must "be justified in precisely the manner referred to by their validity claims."7 (Forst refers to this as a reasonably non-rejectable 'principle of justification.')

(2) People have an unconditional duty to justify themselves to others in accordance with the principle of justification. ${ }^{8}$ (This is what Forst calls the 'duty of justification'-in his view, reasonable people recognize that they have this duty.)

(3) People have a right to justification: we must respect or recognize them as

7 Forst (2012), p. 18.

8 Forst (2012), p. $21 \mathrm{ff}$. 
"worthy of being given adequate, justifying reasons in matters that affect them,"9 or as agents who "can demand acceptable reasons for any action that claims to be morally justified and for any social or political structure or law that claims to be binding upon him or her."10

A note on (3) is in order. Forst writes that to "speak of a right here-and, indeed, of that most basic of all rights of every human being - is to say that it expresses a fundamental, absolutely binding subjective claim that cannot be denied intersubjectively." 11 However, this right is not a right to being given reasons that are 'justifying' by just any standard of justification. Prior to further argument, there are many different, often competing, albeit prima facie reasonable conceptions of the standards of justification, including conceptions of personal, propositional, and interpersonal justification. Consequently, leaving open by what standards our reasons must be 'justifying' to duly respect others' right to justification would effectively trivialize the right in question. For example, in some sense of the term, I 'justify' myself to you if I promulgate what, by my lights, gives me reason (or, say, makes it coherent, or epistemically responsible, for me) to believe that I may treat you as I do-whether or not you could ever accept my reasons. Accordingly, Forst takes it that the relevant standards of justification must be the ones dictated by our validity claims - this is the upshot of (1) and (2) - and he insists that our moral and political validity claims commit us to construe of the interpersonal acceptability of our reasons or principles as something that constitutes their justification (I shall return to this later). At the centre of his variant of constructivism, then, is the following claim:

(4) Moral and political principles raise validity claims such that they depend for their validity, or their justification, on meeting a requirement of reciprocal and general acceptability: such principles depend for their validity, or justification, on being equally acceptable by all affected others. (Forst applies RGA not only to substantive moral and political principles, but to every view, reason, practice, or institution, widely conceived, that is claimed to be morally good, right, valid, correct, or reasonable.) ${ }^{12}$

According to Forst, RGA, just like the principle of justification, the duty of justification and the right to justification, is reasonably non-rejectable. (I will return to this below.) ${ }^{13}$

9 Forst (2003a), p. 76f.

10 Forst (1999), p. 44.

11 Forst (2012), p. 210.

12 Forst invokes RGA, or versions of this requirement, throughout his work. See Forst (2003a), Forst (2012), pp. 6, 20f, 66, 214f; Forst (2014a), pp. 46, 101f, 140. See also below.

13 RGA raises important questions that I must set aside here. For example, as an anonymous reviewer observed, RGA's (alleged) reasonable non-rejectability depends on whether it entails a plausible view of the scope of practical reasoning. That is, who counts as a relevantly affected, relevant person for the purposes of reasoning that is reciprocally and 'generally' acceptable? Forst does not provide much in the way of a vindication of his view of scope. This view comes down to this. First, like other Kantinspired constructivists (on constructivism, see below), Forst opts for a logocentric view of scope: every agent who can have a right to justification potentially is a relevant person, and this includes at least 
While the four views just listed are building blocks of Forst's constructivism that he applies to a wide array of themes, a fifth view is specific for his account of human rights:

(5) Human rights can be justified as entitlements that cannot be denied on reciprocally and generally acceptable grounds within justification discourses that duly respect the right to justification of each affected other.

Forst conjectures that justification discourses that respect the right to justification of each affected person, and that examine whether proposed, rights-allocating principles are suitably acceptable (or non-rejectable), allow us to justify as valid at least some meaningful set of rights to individual liberty and political participation, as well as rights to resources that enable the usage of these rights. ${ }^{14}$ However, he in effect concedes that it is open how, or by what discursive mechanisms, such outcomes can be arrived at. Thus, on the one hand, he suggests that reasoners, in order to determine whether a proposed principle is suitably acceptable, must consider whether it can be arrived at in actual justification discourses. It is in this vein that he insists that political principles are valid only if all relevant people can give their assent to them-but "not just their counterfactual assent but assent based on institutionalized justification procedures." 15 On the other hand, he concedes:

[It is not the case] that all further rights can be "derived" from the right to justification. Contrary to this view ... the basic right [to justification] primarily designates the concrete standpoint of those who demand reasons and rights in particular social situations. The basic right does not determine from the outset which substantial reasons are adequate, which rights can be demanded or which institutions or social relationships can be justified. As the universal core of every internal morality, the right to justification leaves this to the members' specific cultural or social context. ${ }^{16}$

every agent who can reason practically in a way that enables the agent to demand acceptable reasons for actions, practices, or institutions. See Forst (2014b), p. 20f, and Forst (2012), esp. pp. 156-159. Second, while it is unclear how exactly Forst distinguishes relevant from irrelevant effects, he seems to favour a view that emphasizes the recipient's perspective: if Betty acts toward Paul in a way that, by Paul's lights, affects Paul relevantly, this constitutes relevantly affecting Paul (and hence can trigger Betty's duty to justify herself to Paul). However, this emphasis is defeasible: it seems that for Forst, any criterion of relevant effects must be reciprocally acceptable by all affected others. Yet, as critics of Kantinspired constructivism often ask, why should we adopt a logocentric view of scope? What of people who possess the relevant capacities to a lesser degree or not at all-do they have no right to justification, or a lesser right? And why should we identify effects as relevant in such a way (that is noncircular to do so to begin with)? I may leave it to Forst to answer these questions. For an exemplary attempt to determine scope on constructivist grounds, see O'Neill (1996), pp. 91-121; O'Neill (2000), pp. 186-202. I discuss limitations of such attempts in Besch (2011), (2013b) and (2014).

14 Forst (2012), pp. 225f, 262.

15 For this and below, see Forst (2014a), pp. 20f, 23. On reasonableness, see below.

16 Forst (2012), p. 212. 
On Forst's view, then, there might be many different ways to organize justification discourses so that they respect the right to justification of each participant, and allow participants to identify whether proposed principles, rights, or other views, are equally acceptable by all affected others. Now, Forst's constructivism does not show just how this can be done: he stipulates, rather than establishes, that justification discourses can be organized accordingly. 17 And in the absence of an account of how they can be organized accordingly, we might be unable to tell whether there really are, or can be, institutional or discursive mechanisms that allow us to reason with any cogency from a Forst-type right to justification to substantive moral or political conclusions. But, if we are unable to tell this, we cannot know whether that right, mediated through such discourses, can provide a categorical foundation of these conclusions; for we would not know whether the link between that right and these conclusions is of a suitably cogent kind. However, while these concerns are serious, I shall now set them aside. What matters for my purposes in the first instance is the systematic status of the right to justification and RGA and the relationship between these things. For charity's sake, therefore, I will not take issue with (5). Accordingly, let me grant, first, that substantive moral or political principles, including rights-allocating principles, can be arrived at in justification discourses that are organized to suitably respect a Forst-type right to justification, and second, that such discourses can be organized accordingly (whatever form this might take in a given cultural or social context).

With this in place, let us now turn to the two lines of thought in Forst's approach referred to at the beginning of this section. A first line of thought is this. Forst claims that the right to justification is "not a specific, intersubjectively established and recognized human right, but rather the basis of a justification of concrete rights itself." 18 In an exemplary passage, he adds:

The moral basis for human rights ... is the respect for the human person as an autonomous agent who possesses a right to justification, that is, a right to be recognized as an agent who can demand acceptable reasons for any action that claims to be morally justified and for any social or political structure or law that claims to be binding upon him or her. Human rights secure the equal standing of persons in the political and social world, based on a fundamental moral demand of respect. ${ }^{19}$

Thus, an idea of moral respect for people, or their autonomy, gives rise to the view that they must be accorded a right to justification, or be respected as agents who "can demand acceptable reasons for any action that claims to be morally justified and for any social or political structure or law that claims to be binding upon him or her." 20

17 While Forst favours the discursive mechanisms of (a form of) deliberative democracy, he focuses not on outlining what specific institutional shape these mechanisms should have, but on what normative constraints they must meet. See Forst (2012), esp. p. 161ff; Forst (2002), pp. 112-154.

18 Forst (2012), p. 212; my emphasis.

19 Forst (2010), p. 719.

20 Forst (1999), p. 44. 
Accordingly, Forst's requirement of reciprocal and general acceptability-that is, of equal acceptability by all affected others-specifies a condition that moral or political reasons and principles must meet in order to properly accord with the equal right to justification of each affected person. Concrete human rights are then established as entitlements that cannot be rejected on reciprocally and generally acceptable grounds in discourses that respect the right to justification of each affected other.

Forst situates the right to justification in a different way when he highlights the role of the validity claims of moral-political principles:

We need not resort to a metaphysical or anthropological foundation for [human] rights. [They] are to be regarded as constructions ... that have an intersubjectively non-rejectable "reason." They are justified constructs the respect of which moral persons, who see no good reasons to deny them, owe to each other. The basic right to justification reveals itself in a recursive reflection combined with a discursive explanation of what it means to justify individual actions and general norms in a moral context. Any moral norm that claims to be generally and reciprocally valid must be able to prove its validity to those to whom it is addressed according to these criteria. Consequently, it must be able to be the subject of a practical discourse in which, in principle, all arguments for or against the norm can be presented. Thus, if one begins with an analysis of claims to moral validity and asks further for the conditions of their validity, one finds the "simple" principle of justification [i.e., RGA].21

This suggests that the reasonably non-rejectable 'reason' of human rights is RGA plus the view that RGA commits us to accord to others a right to justification. The reason RGA is reasonably non-rejectable is that (i) the validity claims of our moral or political reasons or principles require these things to be equally acceptable to all affected persons, so that (ii) we cannot coherently claim these things to be valid (or correct, right, or reasonable) while rejecting that they depend for their validity on their reciprocal and general acceptability. 22 As to the right to justification, it is "inherent" in RGA. 23 Roughly, the idea appears to be this: where discursive practices fully comply with the requirement of reciprocal and general acceptability, each reasonable participant will recognize that moral and political views, practices, or institutions, depend for their authority (or their validity, rightness, or reasonableness) on their equal acceptability to each affected other. For Forst, this means that each reasonable participant will recognize each affected other as being "worthy of being given adequate, justifying reasons in matters that affect them." 24 That is, the discursive status that RGA requires us to accord to each affected other just is the status that Forst's right to justification asks us to accord to them. As to other, concrete human rights, on this reading, too, they would be established as

21 Forst (1999), p. 44.

22 For Forst, a commitment to justifications that properly redeem our validity claims is part of what characterizes us as reasonable, see Forst (2002), p. 81; Forst (2003a), p. 80f. See also below.

23 For example, see Forst (2002), p. 81.

24 Forst (2003a), p. 76f. 
entitlements that cannot be rejected on reciprocally and generally acceptable grounds in discourses that duly respect the right to justification.

According to the first line of argument just sketched, Forst's approach can provide a reasonably non-rejectable foundation of human rights only if there is an idea of moral respect that at once is reasonably non-rejectable and that commits us to accord to all affected others a Forst-type right to justification. According to the second line of argument, the approach provides the sought-after foundation only if our validity claims commit us to RGA. For Forst's case to succeed, at least one of these lines of argument must succeed. I shall further elaborate on, and engage, the second line of argument in the next section. After this, in Sections 4 and 5, I will focus on the first line of argument.

\section{The Argument from Validity Claims}

The second line of argument turns on two views:

(6) Our moral-political validity claims must be reconstructed such that, where we claim moral or political principles to be right, we cannot coherently reject that they must be justifiable on grounds that are reciprocally and generally acceptable.

(7) The requirement of reciprocal and general acceptability commits us to accord to other people a right to justification.

Let me grant (7) in order to comment on (6) as this is the systematically more fundamental view.

Consider first what Forst's requirement of reciprocal and general acceptability calls for. Principles are general in RGA's sense only if they are acceptable to everyone affected by them; this commits us to a form of justificatory universalism. 25 As to reciprocity, Forst claims that RGA requires reciprocity "of content" and "of reasons." 26 Reciprocity "of content" minimally requires that we treat like cases alike, and so calls for a form of formal impartiality. Reciprocity "of reasons" effectively imports a demand of equal acceptability, or non-rejectability. Thus, RGA is universalist and egalitarian, each term suitably understood. RGA is also a constructivist standard. For Forst, reciprocal and general acceptability does not flow from, but constitutes, the validity of principles and the goodness of reasons. This instantiates a constructivist conception of the link between the acceptability and the epistemic-practical authority-e.g., the validity, rightness, or reasonableness - of principles or reasons; roughly, constructivists take it that acceptability can constitute epistemic-practical authority, or justification. 27 That acceptability can have such a strong, justification-constitutive rank is denied by anticonstructivists, such as Platonists, moral realists, or perfectionists. ${ }^{28}$ Anti-constructivists

25 See Forst (2010), p. 720.

26 Forst (2010), p. 719. See also Forst (2002), p. 38ff.

27 On the wide notion of constructivism that I employ here, see Besch (2014). See also Ronzoni (2010) and LeBar (2008).

28 On the difference between constructivism and these forms of anti-constructivism, see O'Neill (1996), p. 54ff; O’Neill (2000), pp. 13-28. See also O'Neill (1989), esp. pp. 206-218. 
can still attach much value to acceptability. For instance, they might see it as a desirable by-product of justifications, or as a non-justificatory condition of the political legitimacy of just policies. And they might also concede that there is a close link between the authority and the acceptability of principles or reasons; after all, if good reasons are intellectually accessible at all, there is a sense in which they are a possible object of wide acceptance, namely, by all people who are capable of appreciating good reasons as good. Yet, anticonstructivists reverse the constructivist order of dependency: rather than taking the goodness of good reasons to depend on their acceptability, they take the acceptance of good reasons to be rational if it derives, or can derive, from an appreciation of their goodness. Thus, they seek "ideal" unanimity (Nagel), or "normative" consent (Estlund), 29 and see (relevant) acceptability not as a justification-constitutive, but as a justificationderivative property.

Should we take it, then, that our moral and political validity claims must be reconstructed as committing us to RGA? As I have argued elsewhere, an adequate reconstruction of our validity claims will not imply that they by themselves commit us to RGA. 30 Here is the crux of the issue. To be fully adequate, a reconstruction of the practice of raising validity claims must be true of at least all its competent and reasonable instantiations-'competent' and 'reasonable,' that is, as construed prior to settling the truth about justification, good reasons, and constructivism. And to initially arrive at such a reconstruction, equal charity must be extended to all its reasonable participants. Thus, we should reconstruct their discursive activities in ways that maximize, rather than selectively decrease, their intelligibility and coherence. Now, for better or worse, reasonable participants in the relevant practice often disagree about the requirements of justification in a given context and about the kind of moral status that we should accord to other people. Reasonable people might agree that we need to give others good reasons in support of our validity claims-evidently, constructivists and nonconstructivists alike can accept this-but there are reasonable people who cannot in fact accept coherently that the goodness of good reasons is a function of their equal acceptability to all affected others. Included in this group are anti-constructivist, such as Platonists, moral realists, many perfectionists, but also constructivists who deny that equal acceptability to all affected others counts, rather equal acceptability by the reasonable, or the rational, or the right-minded.

If this is so, we should reconstruct our moral-political validity claims in terms that are abstract or minimal enough to remain neutral between pro-constructivist and conconstructivist doctrines of how best to raise or redeem them. And this disables the inference from our validity claims to RGA. If a reconstruction of the practice of raising moral or political validity claims entails that they by themselves commit us to a constructivist standard, such as RGA, then it is not suitably neutral between proconstructivist and con-constructivist stretches of that practice. Hence there is reason to doubt that it adequately reconstructs all prima facie reasonable instantiations of that practice (as opposed to pro-constructivist instantiations only). But if a reconstruction of this practice is suitably neutral between its pro-constructivist and con-constructivist

29 Nagel (1991), p. 33f; Estlund (2008), p. 10.

30 Besch (2013a). 
instantiations, then it may be adequate, but it cannot show that our moral or political validity claims by themselves commit us to RGA.

In short, unless we suppose that only pro-constructivist instantiations of the practice of raising moral or political validity claims are competent or reasonable-which, in the context at hand, would beg the question-a reconstructively adequate account of this practice cannot entail that raising moral-political validity claims commits to RGA. Hence we should reject claim (6), above. 31

\section{The Argument from Moral Respect}

This brings me to the second line of argument in Forst, i.e., his argument from moral respect. On this reading of his approach, we saw earlier, an idea of moral respect grounds the right to justification, while RGA specifies a condition that justificatory discourses must meet to accord with the equal right to justification of each affected person. Concrete human rights are then established within justificatory discourses that meet this condition. Would such an idea of respect allow for a categorical, reasonably non-rejectable grounding of human rights? I shall suggest that this is not so. To commit us to a Forst-type right to justification, moral respect must be understood in a special way-it must be understood as 'discursive respect,' as I will call it. But any conception of moral respect as discursive respect will be the subject of reasonable disagreement.

As a point of departure, let me distinguish between moral standing and discursive forms of such standing. Where we take others to have moral standing-or accord them baseline moral status, or include them in the scope of our moral concern-we take it that there are non-instrumental, moral reasons to protect or support them, or their good. Where we accord discursive forms of moral standing, in turn, we take it that the way in which others may be related to, e.g., in protecting or supporting them, must follow grounds, widely conceived, that are, in some relevant sense, acceptable to them. Now, there are at least two kinds of discursive standing, i.e., constitutive kinds and weaker, derivative kinds. Let me suppose that where we are reasonable, we are committed to acting on grounds that, at least as far as we can tell at the time, are good. Thus, where reasonable Betty accords to Paul constitutive standing, she is committed to acting toward him on grounds that are good and acceptable, but she takes it, as well, that the goodness of these grounds is at least partly a function of, or is constituted by, their acceptability to Paul. Where she accords to Paul derivative standing, in turn, she is committed to acting toward him on grounds that are both good and acceptable, but rather

31 Note that I did not suppose above that constructivist and non-constructivist standards of justification are equally reasonable all things considered. Instead, I argue that, unless we have already established what standards to accept, we should reconstruct our validity claims in suitably neutral terms. This does not mean that there are no good, independent reasons to accept constructivism (or non-constructivism, for this matter). Forst cannot object that all that is needed for the view that our validity claims commit us to RGA is that they commit us to a practice of reason-giving. Yes, they might commit us to such a practice (if we are reasonable). But this does not suffice for Forst. A commitment to RGA is a commitment not simply to a practice of reason-giving. Rather, it is a commitment to go about such a practice in a very special way-namely, by adhering to the constructivist view that it is the equal acceptability of reasons by all affected others that makes them good. And this imports a view of justification that is reasonably contested, and that needs independent argument. For an intriguing recent attack on such a view, see Steinhoff (2015). I am indebted to an anonymous reviewer for drawing my attention to the need to highlight this here. 
than taking their acceptability to be a condition of their goodness, she takes their acceptability, or valuable forms of it, to derive from, or be a consequence of, their goodness. To mark this contrast, I shall speak of discursive respect where we accord constitutive form of discursive standing. 32

The difference between these two kinds of discursive standing matters greatly, but it should not be overdrawn: constitutive and derivative discursive standing are located on opposite ends of a sliding scale, thus allowing for many intermediate forms of discursive standing. At the level of theory, moral and political constructivism typically expresses a commitment to discursive respect at whatever level of thought such views apply a constructivist acceptability standard. For example, constructivist conceptions of justice take it that (qualified) acceptability to relevant other people constitutes the authority of principles of justice, or, say, their validity, rightness, or reasonableness, and so on. Such views thereby accord to the relevant others constitutive discursive standing, even though they may differ deeply about the nature, grounds and the boundaries of such standing. Let us observe again, though, that even if we adopt a variant of anti-constructivism, we can still attach value to the acceptability of principles. For example, we might take it that it is part of the human good that people can come around to accepting the principles that apply to them, or that their free support is necessary for the stability of a just regime, or that it promotes perfection in the polity as a whole. Yet, in relation to these principles we would accord to people a form of the weaker, derivative kind of discursive standing.

Let us apply this to the case at hand. For Forst, as for many other Kantians, moral respect requires discursive respect. To duly respect others, the assumption is, we must accord them constitutive discursive standing-this being the kind of standing that a Forst-type right to justification calls for. But why construe moral respect in these strong terms? Even if we agree that we should accord to other people discursive standing, why must we construe this as constitutive discursive standing? As it stands, there is nothing wrong conceptually with the view that moral respect requires moral concern and derivative discursive standing only. Normatively, it might ask for more-and that it does this is part of the point of Forst's view that people should be accorded a right to justification that calls for justifications that meet RGA. But just how demanding and doctrinally selective can a conception of moral respect become before it fuses with normative, evaluative, or other content that renders it the subject of reasonable disagreement? Even if we conceptually tie reasonableness to moral respect-so as to taking it that it is unreasonable not to morally respect others-it does not follow that it is unreasonable to reject constructivist interpretations of moral respect. And that this is so can (and should) be conceded even where we take it that such conceptions are right, or particularly plausible: for that a view is right does not mean that those who do not accept it are unreasonable, nor does its plausibility entail the unreasonableness of people who are not like-minded.

In short, even if the reasonableness is conceptually tied to moral respect, it does not follow that it is unreasonable to reject a commitment to discursive respect. There is more than one kind of discursive standing; and, as I assumed all along, there is reasonable controversy about the justificatory status of acceptability. Prior to further argument, then, to construe moral respect as discursive respect is to construe moral

32 I discuss discursive respect in Besch (2014). 
respect in terms that are reasonably contentious. If that is so, no conception of moral respect as discursive respect can provide a categorical, reasonably non-rejectable foundation for human rights-even if we agree that it is unreasonable not to morally respect all affected others, and even if we take it that we should accord them discursive respect.

\section{On Moral Concern and Discursive Respect}

Let me substantiate this further by considering the relationship between moral concern and discursive respect. Evidently, they can come apart. This is plain where we include beings in the scope of moral concern that lack a capacity for (direct) discursive inclusion, such as non-human animals. But they can come apart even in the case of people. For instance, some forms of constructivism accord discursive respect to subsets of affected people only, without accordingly restricting the scope of moral concern. Take Rawls-type political liberalism. Arguably, political liberals accord discursive respect, or constitutive discursive standing, only to people who are reasonable in a special, substantive sense. But political liberals do not deny that unreasonable people matter morally, and they insist that the unreasonable should be engaged in non-justificatory political arguments that aim to persuade them not to reject reasonable principles. Thus, political liberalism accords to the unreasonable discursive standing, yet a standing of the weak, derivative kind. 33 Logically (though perhaps not ethically) this is unobjectionable. That (i) Paul should be included in the scope of moral concern and that (ii) Paul has a capacity for inclusion in the scope of discursive respect does not by itself entail (iii) that Paul must be acted toward on grounds he can accept-construed in terms of constitutive discursive standing. Since (i) and (ii) leave open how we are to respond to the presence of the relevant capacity in Paul, (iii) does not follow unless we supply an additional view to the effect that the presence of the relevant capacity in Paul is a reason to accord to him constitutive discursive standing.

What sort of views can tie moral concern to discursive respect? How does the former, if crossed with the recognition of suitable discursive capacities in others, commit us to the latter? One answer that springs to mind is this: moral concern, we have seen, involves a commitment to protecting or supporting others, or their good. Thus, to have any determinacy, such concern must draw on some notion of what it takes to protect or support others, or their good. A self-suggesting source of a link between moral concern and discursive respect thus are conceptions of the good that place a premium on constitutive discursive standing. Moral concern does commit us to discursive respect if we take it to be a good not only that we be interacted with on grounds that we can accept, but also that we interact with others on grounds that they can accept (where the goodness of these grounds is taken to depend on their acceptability).

For just one example of such a conception of the good, take Postema's view that people desire to be recognized as "robust" moral selves, or as people who are governed by an "ideal of reasonableness" and so are interested in pursuing not just aims "that they

33 For example, Stephen Macedo prescribes that unreasonable people be "re-engaged" after the principles of justice are established to persuade them to accept these principles. See Macedo (1991), p. 61ff. Likewise, Rawls argues that the unreasonable should be addressed, but by non-justificatory arguments 'from conjecture,' see Rawls (1997). See also Besch (2013b) and (2012). 
judge as worthy, but ... in pursuing aims that are worthy."34 Even though Postema does not use these terms, he argues that this desire asks us to accord to one another discursive respect and that this commits us to "robust," constructivist public justification. Lesser recognition, he insists, is inadequate for us. 35 However, this latter claim holds only to the extent that people attach importance to being seen by others as getting moral-political matters right (rather than other matters) and so it depends, amongst other things, on how deeply invested they are in such matters and on how much room they give them in relation to their other aims, commitments, or attachments. Of course, it also depends on whether sharing a practice of constructivist public justification is a suitable means to the end of securing that recognition-which it can be only if such justification is, or is seen to be, able to establish that things really "are worthy." Plainly, the comparisons, rankings and value judgments that these things call for, as well as the constructivist conception of justification that goes with it, invite reasonable disagreement. This suggests that robust moral selfhood is not a Rawls-type primary good, or a thin, reasonably non-rejectable good. 36 Rather, it is a reasonably contestable conception of the good.

I hasten to add that while views of the good that place a premium on constitutive discursive standing are reasonably contestable, this may not be true of views like:

(8) It is an important good that I (or we) be interacted with on grounds I (or we) could accept.

(9) It is an important good that I (or we) interact with others on grounds they could accept.

(8) and (9) mark recipient-centered and author-centered views of the good of discursive standing. As they do not discriminate between derivative and constitutive forms of that standing, all they might call for are actions that are based on grounds that are good and for this reason acceptable (say, at least by the right-minded). Now, acting on grounds that are good is something we are committed to anyway if we are reasonable. Understood as views about derivative discursive standing, then, (8) and (9) seem to reflect different sides of the good of interacting reasonably - a good that, it seems, reasonable people cannot coherently reject.

Here is another observation on the status of constitutive discursive standing: what value this standing has for its recipients can vary depending on what it takes for grounds (reasons, or principles) to be suitably acceptable to them. Any conception of discursive respect must attach some interpretation to the idea of acceptability at its core, and different interpretations yield conceptions of discursive respect that differ in purchase. ${ }^{37}$ Discursive respect has much purchase for you if I am to regard the fact that you are now committed to reject my reasons, given your actual views and volitions, as showing that they are not suitably acceptable to you-suitably acceptable, that is, as called for by

34 Postema (1995), p. 82.

35 Postema (1995), p. 82.

36 Rawls (1972), pp. 61, 395ff, 407-424.

37 On purchase as a dimension of discursive respect, see Besch (2014). 
discursive respect. Discursive respect can have little purchase for you if I take my reasons to be suitably acceptable to you so long as I see reason to believe that you would not reject them if you considered them in what $I$ take to be the right light-say, even if it is incoherent for you to accept them or to ever consider them in that light. And, evidently, there is much middle ground between an actualist view of discursive respect that takes a simple rejection as showing that the needed kind of acceptability does not obtain, and a counterfactualizing view that can end up neutralizing the impact of wellconsidered rejections where they do not meet exclusionary threshold-tests of some sort or other. Part of what we do in calibrating the purchase of discursive respect, then, is to settle what baseline normative impact people's actual views and volitions have on the grounds that, we take it, may govern interactions with them. Arguably, we thereby also link discursive respect to some view of the minimum degree of deliberative competency that, we believe, others must have for their rejections of our grounds to constitute reasons to doubt our grounds, or to even exercise, as Forst sometimes puts it, a "veto."38

Now, we saw earlier that, while moral concern commits us to discursive respect where we suppose a conception of the good that places a premium on constitutive discursive standing, such conceptions are the subject of reasonable disagreement. More such disagreement is inevitable where we consider not only whether this standing is a good, but account for, or calibrate, what purchase it should have-be this disagreement about the merits of the practices of reasoning that different calibrations call for, or the desirability of the forms of life they enable, or the plausibility of the ideas of deliberative competency that they encapsulate. This corroborates further that a commitment to (calibrated) discursive respect is reasonably contestable. Even if reasonableness is tied to moral respect and requires us to accord to others discursive standing, it remains reasonably contestable whether we should also accord them discursive standing of the strong, constitutive variety - where this is the standing for which a Forst-type right to justification calls. In addition, even if we agree that it is unreasonable not to accord others constitutive discursive standing, or a Forst-type right to justification, we can still reasonably disagree as to what purchase this standing should have. Thus, we should conclude that Forst's argument from moral respect does not provide a reasonably nonrejectable foundation of human rights.

\section{Constructivist Reasonableness?}

None of the above argues that we should not accord to other people discursive respect, or a right to justification. Instead, the above suggests that neither our validity claims, nor the commitment to respecting others morally, makes it unreasonable for us not to accord to others these things. For all we have seen, Forst's approach is subject to fatal nonsequiturs: it remains open why what this approach appeals to as a reasonably nonrejectable foundation of human rights indeed is reasonably non-rejectable.

From a hermeneutic standpoint, non-sequiturs of this deep kind sometimes herald the presence of tacit suppositions. This brings me to Forst's idea of reasonableness. I supposed all along that RGA and a commitment to discursive respect can reasonably be rejected. Evidently, Forst disagrees. He takes it that reasonable people recognize that

38 Forst (2010), p. 719; Forst (1999), p. 44. 
they have an "unconditional duty" to justify themselves to others in accordance with a "principle of justification" to the effect that practical views, widely conceived, must "be justified in precisely the manner referred to by their validity claims." 39 However, he seems to from the outset suppose:

(10) Reasonable people recognize that others have a right to justification (understood as a right to constitutive discursive standing, or discursive respect).

(11) Reasonable people accept the requirement of reciprocally and generally acceptability. 40

If a constructivist idea of reasonableness like this is supposed, Forst's constructivism might escape the problems noted here. Perhaps an account of the practice of raising validity claims can be reconstructively adequate even if it is true only of pro-constructivist ways to participate in this practice if only they are competent or reasonable. And perhaps an idea of moral respect as discursive respect can provide a categorical foundation of human rights if a commitment to discursive respect is part of what defines us as reasonable in the first place. Let us consider, then, whether Forst's constructivism may suppose a constructivist idea of the reasonable.

A first concern is this: Forst's constructivism aspires to provide a categorical, reasonably non-rejectable foundation of human rights, and it offers as such foundations a Forst-type right to justification and RGA. Now, if Forst's constructivism can coherently suppose (10) and (11), he may be able to claim that these things are 'reasonably' nonrejectable. But this does not accomplish what Forst is after. Surely, categorical foundations of human rights (or of anything else) are not foundations that are 'reasonably' non-rejectable in terms of just any doctrinal conceptions of the reasonableand, evidently, there are many competing conceptions of the notion 41 -but in terms of a conception of the reasonable that we truly should or must accept (whatever it may be). At the same time, Forst's constructivist idea of the reasonable is the subject of reasonable objections if constructivism is the subject of such objections, and this, if anything, puts this idea in need of justification. 42 Why, then, should we accord to all affected others equal constitutive discursive standing? Even if Forst can coherently suppose (10) and (11), prior to answering this question, his account justifies human rights not categorically, but-much like its 'ethical' counterparts—at best hypothetically by grounding them in a commitment to the good of (equal) constitutive discursive standing - a good, though, that is reasonably contested and that stands in need of justification.

However, it is unclear that Forst's constructivism can coherently suppose (10) and (11). With this, I turn to a second concern: it seems self-undermining for Forst to suppose

39 Forst (2012), p. 18; see also p. $21 \mathrm{ff}$.

40 See Forst (2003b), p. 649ff; Forst (2003a), p. 80f; Forst (2002), Chapter 4.

41 See Moore (1996).

42 I here use the term 'reasonable' in an intuitive, non-technical, but inclusive sense that allows for the possibility of reasonable non-constructivism. While this is all that is needed now, I briefly touch on what content such an idea might have below. On reasonableness, see Besch (2012), (2013b); Moore (1996). 
a constructivist conception of reasonableness if indeed all affected others have a right to justification-assuming, that is, we adopt a deep view of that right, or of discursive respect. To see why this is so, consider first that conceptions of discursive respect can differ in their depth in the order of justification. Discursive respect varies in depth depending on the level of thought, argument, or decision-making, at which a commitment to the constitutive discursive standing of other people is expressed. 43 This commitment can be applied at many different levels of thought, including, but not limited to, these (they are listed in the order of increasing depth):

(i) the selection of reasons for action: e.g., $R$ is a good reason to do $A$ only if $R$ is suitably acceptable as such a reason to all affected others;

(ii) the justification of first-order practical principles: e.g., for principles of justice to be valid, they must be suitably acceptable to all affected others;

(iii) the selection of standards of practical justification: e.g., for anything to qualify as a standard of the correctness (or rightness, validity, reasonableness) of political principles, it must be suitably acceptable to all affected others.

(iv) standards of reasoned thought: for any stretch of thought to be genuinely reasoned or reasonable, it must be such that it could coherently be accepted to all others for whom it is to count. 44

Forst for the most part takes it that the right to justification imposes a constraint on the selection of first-order principles and reasons, substantive policies, or political institutions. But there is no a priori reason to leave things there, and Forst himself does not. The right to justification asks us to recognize others as "worthy of being given adequate, justifying reasons in matters that affect them," 45 rather than in matters that exclusively are located at a particular level of thought. Accordingly, Forst takes this right to impose a constraint on the justificatory foundations to which an account of human rights appeals; after all, he rejects justifying human rights on reasonably contested, 'ethical' grounds since these are not equally acceptable to all relevant others.

Prior to further argument, then, Forst's right to justification does its normative work at any level of thought at which other-affecting moral or political validity claims are being raised. Now it is plain that it can significantly affect people which ideas of reasonableness a polity treats as basic enough to suppose in public political discourses. Politically basic ideas of the reasonable play an important and complex role in the political and discursive inclusion of people as equals, insiders, or as 'right-minded'; accordingly, discrediting dissenters as 'unreasonable' often is part of attempts to stifle, override or neutralize their voices. Other things being equal, then, a Forst-type right to justification should be deep enough to impose constraints on the ideas of reasonableness that we suppose in moral-political justification. However, for better or worse, a constructivist idea of the reasonable is not reciprocally acceptable to all affected

\footnotetext{
43 On depth as a dimension of discursive respect, see Besch (2014).

44 This is O'Neill's view: see O'Neill (1988) and (1992); see also O'Neill (1996), Chapter 2.

45 Forst (2003a), p. 76f; emphasis is mine.
} 
others - there are prima facie reasonable people who (rightly or wrongly) cannot in fact accept constructivism coherently. This is so at least if we take it, as Forst does, that reasonable disagreement about a view rules out its reciprocal and general acceptability. 46 If all this is so, then it is self-undermining for Forst's constructivism to presuppose a constructivist idea of the reasonable.

It is better aligned with the inclusivist spirit of the view that all affected others should be accorded equal right to justification if moral-political justification builds on an idea of the reasonable that abstracts from purported, doctrinal elements of reasonableness that are the subject of persistent and intelligent controversy. Elsewhere, I have made suggestions as to what content such an idea of the reasonable might have. 47 For example, it might have content associated with the meaning of the word 'reasonable' (as it is used in relation to people in their capacity as moral-political agents). As Moore points out, as per the meaning of the word, 'reasonableness' involves a commitment to a practice of reason-giving and reasonable people take it that others are worthy of reason-giving and at least some minimum consideration. 48 But this implies neither that reasonable people are committed to a constructivist practice of reasongiving, nor that they must accord to others constitutive discursive standing, rather than discursive standing of the weaker, derivative kind. There may be more content that may be built into a suitably inclusive, non-doctrinal idea of the reasonable. 49 But whatever content we may build into this idea, it may not by itself entail that RGA and the commitment to discursive respect are reasonably non-rejectable-especially if this idea, or justification practices that comply with it, are to cohere with the view that all affected people have an equal and deep right to justification.

\section{Conclusion}

I engaged two lines of argument in Forst. A first line of argument offers as the soughtafter foundation of human rights a view to the effect that our validity claims commit us to RGA and that RGA commits us to a Forst-type right to justification. I argued that an adequate reconstruction of our validity claims will not entail that they commit to RGA. The second line of argument offers as the sought-after foundation of human rights a conception of moral respect as discursive respect. RGA is then taken to specify a condition that principles and reasons must meet to comply with the constitutive discursive standing of each affected person. Yet even if reasonableness commits us to moral respect, it does not thereby commit us to (calibrated) discursive respect, or to RGA. These things are the subject of reasonable disagreement. Finally, I argued that Forst cannot suppose a constructivist conception of the reasonable.

Forst's constructivism, then, does not justify human rights on categorical, reasonably non-rejectable grounds. At best, it grounds them hypothetically in a commitment to the good of constitutive discursive standing. Many might agree that this is an important good, and my discussion is consistent with the view that, indeed, it is an

46 Forst (2003a), p. 80f; Forst (2012), p. 86.

47 See Besch (2013b), p. 70ff; Besch (2012).

48 Moore (1996), p. 171.

49 See Besch (2013b). 
important good. But whatever its appeal, anchoring human rights in a commitment to this good is to build them on grounds that are reasonably contested, and that stand in need of justification. Thus, the question remains why we should construe moral respect as discursive respect, or why we should value (equal) constitutive discursive standing-and, of course, how exactly we should calibrate it. Evidently, this opens the door wide for an 'ethical' defence of the good of constitutive discursive standing. It is unclear to what extent an 'ethical' defence of this good can cohere with the good that it defends. For such a defence will inevitably invoke value judgments that will be the subject of reasonable disagreement, and that hence may not be equally acceptable to all affected others if 'acceptability' retains much purchase. It is an open question how best to calibrate constitutive discursive standing in response to this problem. In any case, the fact that this would provide a merely hypothetical justification of human rights on reasonably contested grounds would not constitute an objection that is available from the perspective of Forst's constructivism.

Acknowledgements: For discussions of ideas included here or in earlier versions of this paper, I am indebted to Paul Patton, Moira Gatens, Duncan Ivison, Nikolas Kompridis, Rainer Forst, Uwe Steinhoff, Ben Cross, Stuart Wong, Sabine I. Jentsch, Jung-Sook Lee, several student groups at the University of Sydney, as well as attendees of presentations at the University of New South Wales, the University of Sydney, the University of Hradec Kralove, Lingnan University, Charles University, Bogazici University and Wuhan University.

\section{References}

Beitz, C.

2009 The Idea of Human Rights. Oxford: Oxford University Press.

Besch, T. M.

2011 "Kantian Constructivism, the Issue of Scope, and Perfectionism: O'Neill on

Ethical Standing." European Journal of Philosophy, Vol. 19/1, 1-20.

Besch, T. M.

2012 "Political Liberalism, the Internal Conception, and the Problem of Public Dogma." Philosophy and Public Issues (New Series), Vol. 2/1, 153-177.

Besch, T. M.

2013a "On a Reflexive Case for Human Rights." Journal of East-West Thought, Vol. 3/4, 51-64.

Besch, T. M.

2013b "On Political Legitimacy, Reasonableness, and Perfectionism." Public Reason, Vol. 5/1, 58-74.

Besch, T. M.

2014 "On Discursive Respect." Social Theory and Practice, Vol. 40/2, 207-231.

Estlund, D.

2008 Democratic Authority. Princeton: Princeton University Press.

Forst, R.

1999 "The Basic Right to Justification: Toward a Constructivist Conception of Human Rights." Constellations, Vol. 6/1, 35-60.

Forst, R. 
Forst R.

2002 Contexts of Justice. Berkeley: University of California Press.

2003a "Toleration, Justice and Reason." In The Culture of Toleration in Diverse Societies, eds. C. McKinnon and D. Castiglione, Oxford: Oxford University

Forst, R. Press, 71-85.

Forst, R.

2003b Toleranz im Konflikt. Suhrkamp: Frankfurt am Main.

Forst, R.

2004 "The Limits of Toleration." Constellations, Vol. 11/3, 312-325.

2010 "The Justification of Human Rights and the Basic Right to Justification: A Reflexive Approach." Ethics, Vol. 120/4, 711-740.

Forst, R.

2012 The Right to Justification. New York: Columbia University Press.

Forst, R. (ed.)

2014a Justice, Democracy and the Right to Justification. London: Bloomsbury

Forst R.

Publishing.

2014b Justification and Critique. Cambridge: Polity Press.

Griffin, J. P.

2008 On Human Rights. Oxford: Oxford University Press.

Larmore, C.

1996 The Morals of Modernity. Cambridge: Cambridge University Press.

Larmore, C.

2008 The Autonomy of Morality. Cambridge: Cambridge University Press. LeBar, M.

2008 "Aristotelian Constructivism." Social Philosophy and Policy, Vol. 25/1, 182213.

Macedo, S.

1991 Liberal Virtues. Oxford: Clarendon Press.

Moore, $\mathrm{M}$.

1996 "On Reasonableness." Journal of Applied Philosophy, Vol. 13/2, 167-178.

Nagel, $\mathrm{T}$.

1991 Equality and Partiality. Oxford: Oxford University Press.

O'Neill, O.

1988 "Ethical Reasoning and Ideological Pluralism." Ethics, Vol. 98/4, 705-722.

O'Neill, O.

1989 Constructions of Reason. Cambridge: Cambridge University Press.

O'Neill, O.

1992 "Vindicating Reason." In The Cambridge Companion to Kant, ed. P. Guyer, Cambridge: Cambridge University Press, 280-308.

O'Neill, O.

1996 Toward Justice and Virtue. Cambridge: Cambridge University Press.

O'Neill, O.

2000 Bounds of Justice. Cambridge: Cambridge University Press.

Postema, G. F.

1995 "Public Practical Reason: An Archeology." Social Philosophy and Policy, 
Vol. 12, 43-86.

Rawls, J.

1972 A Theory of Justice. Oxford: Oxford University Press.

Rawls, J. 1993 Political Liberalism. New York: Columbia University Press.

Rawls, J.

1997 "The Idea of Public Reason Revisited." The University of Chicago Law Review, Vol. 64, 765-807.

Rawls, J.

Rawls, J. 1999 The Law of Peoples. Cambridge (MA): Cambridge University Press.

2001 Justice as Fairness: A Restatement. Cambridge: Harvard University Press. Ronzoni, M.

2010 "Construction and Practical Reason: On Intersubjectivity, Abstraction, and

Steinhoff, U. Judgment." Journal of Moral Philosophy, Vol. 7/1, 74-104.

2015 "Against Equal Respect and Concern, Equal Rights, and Egalitarian Impartiality." In Do All Persons Have Equal Moral Worth?, ed. U. Steinhoff, Oxford: Oxford University Press, 142-172.

Tasioulas, J.

2007 "The Moral Reality of Human Rights." In Freedom from Poverty as a Human Right, ed. T. Pogge, Oxford: Oxford University Press, 75-102.

Quong, J.

2011 Liberalism Without Perfection. Oxford: Oxford University Press.

Waldron, J.

1987 "Theoretical Foundations of Liberalism." Philosophical Quarterly, Vol. $37 / 147,127-150$. 